\title{
Caught By Private Law: A Review Of Visitors' Jurisdiction In Canada
}

\section{Adam Strombergsson-Denora*}

Visitors, an office in charitable corporations that occupies the position of the Superior Court in all matters pertaining to the charity, are a forgotten area of law in Canada. This article resurrects the jurisdiction by explaining its utility for university corporations. Visitors are private courts of appeal from university decisions. They are empowered to adjudicate academic as well as legal disputes relating to relationships between the university, its officers, its professors, and its students. The article lays out the private law origins of the office and contrasts this approach with the administrative law model more recently in vogue. The administrative law approach to visitation has, over the course of the twentieth century, eroded the jurisdiction, yet it appears from Canadian practice that the jurisdiction remains eminently useful across the country. The article details just how the visitor's office has been used in Canadian universities beginning in 1803 going up to 1992. In so doing, the office's strong points as well as its weaknesses are discussed.

Le bureau d'inspection ("Visitors»), qui est un organe des sociétés à fin charitable exerçant les fonctions de la Cour supérieure dans tous les aspects liés à l'activité caritative, représente un aspect du droit qui est oublié au Canada. Dans cet article, l'auteur se penche sur cet organe en expliquant son utilité pour les sociétés universitaires. Les « bureaux d'inspection » sont des tribunaux d'appel privés chargés de réviser en appel les décisions universitaires. Ils ont le pouvoir de trancher les différends de nature tant scolaire que juridique qui concernent les relations entre l'université, ses dirigeants, ses professeurs et ses étudiants. L'auteur retrace dans son article les origines de l'organe en droit privé et le compare avec le modèle plus moderne du droit administratif. En raison de l'approche du droit administratif à l'égard de la fonction d'inspection, la compétence du bureau d'inspection a peu à peu été rongée au cours $d u X X^{e}$ siècle. Pourtant, il appert de la pratique canadienne que cet organe demeure remarquablement utile dans l'ensemble du pays. Dans cet article, l'auteur décrit comment le bureau d'inspection a été utilisé dans les universités canadiennes depuis 1803, et jusqu'en 1992, en commentant au passage les points forts et les points faibles de l'organe.

The Alberta Court of Appeal made recent reference to the long-forgotten office of university visitor when adjudicating a Charter claim to freedom of expression:

* I am completing a law degree at the University of Ottawa and hold and MA in English Literature. My thesis focused on seventeenth-century political rhetoric and poetics in Andrew Marvell's poems. While maintaining a passion for literary history, I am increasingly turning my mind to Canadian legal history, with a focus on religion, conscience, administrative procedure, and constitutional law. I am also author of Warring Sovereignties, a history of the University of Ottawa's turn from a religious to a non-denominational institution. All my thanks to Steve Lorteau, who patiently commented on drafts. Joël Georges Joseph Rocque has inspired the work with his joking incredulity. Paul Daly was kind enough to review my work very late in the game. My partner, Sandra, has also had to bear constant blathering about this office: her forbearance means so much. Suzanne Belson and the Ven. Dr. Edward Simonton really encouraged this study in its early phases. Their interest and support has sustained me in this work. 
the historic role of the Visitor has been for centuries very much that of an ombudsman, and inquirer and a judge of performance of university affairs by its operational masters. From its starting point, then, the University and its purposes were a subject of great significance to the Crown when it enacted the University into existence under s 93 of the Constitution Act, 1867.

The judges in appeal left the analysis of a visitor largely unexplored in the context of Charter litigation. The relationship, however, between private and government charity is relevant when courts are asked to decide whether the Charter applies in litigation. This relationship becomes essential when, as seen in Alberta, a group challenges a University's decision to limit freedom of expression. Emphasising the historical knowledge relating to the visitor's office enriches arguments about Charter claims against charities in receipt of state sponsorship. An historical analysis of the jurisdiction is needed to determine the state of the Canadian law of visitation and to show how courts might consider the office's historical importance in relation to other legal arguments.

Indeed, Canadian law of visitation has been largely left out of academic consideration as a means for access to justice in universities, yet select few scholars ${ }^{2}$ who have taken an interest in the office debate its utility as a local forum - a private court of the founder that, in the words of Chief Justice Holt, "is an appointment of law; it arises from the property which the founder had in the lands assigned to support the charity; and as he is the author of the charity, the law gives him and his heirs a visitatorial power, that is, an authority to inspect their actions, and regulate their behaviour, as he pleaseth". ${ }^{3}$ By this rule, a person or combination of persons can be made visitors simply by the initial transfer of property for the charitable purpose of incorporating a disadvantaged group. The traditional visitor's purpose is to quickly settle disputes in a charity before they undermine the charity's objectives. ${ }^{4}$ Canadian courts have not much considered this law even though hospitals, ${ }^{5}$ universities,${ }^{6}$ churches, ${ }^{7}$ prisons, ${ }^{8}$ and law societies ${ }^{9}$ have or

UAlberta Pro-Life v Governors of the University of Alberta, 2020 ABCA 1 at para 106.

2 William Ricquier, "The University Visitor" (1977) 4 Dal LJ 647 at 676, 682-4; G L Peiris, "Visitatorial Jurisdiction: The Changing Outlook on an Exclusive Regime" (1987) 16 Anglo-Am LRev 376 at 406-7; S Robinson, "The Office of Visitor of an Eleemosynary Corporation: Some Ancient and Modern Principles" (1994) 18 UQLJ 106 at 111; Anwar N Khan \& Alan G Davison, "University Visitor and Judicial Review in the British Commonwealth (Old) Countries" (1995) 24 JL \& Educ 457 at 458; Peregrine W F Whalley \& Gillian R Evans, "The University Visitor - An Unwanted Legacy of Empire or a Model of University Governance for the Future" (1998) 2 Macarthur LR 109 at 125-6.

3 Philips v Bury, [1694] Holt, KB 715, 90 Eng Rep 1294 [Philips] at 1299.

4 Saint John's College, Cambridge v Todington, [1757] 1 Burr 158 (KB), 97 Eng Rep 245 [Saint John's College] at 199200.

$5 \quad$ For e.g. Toronto General Hospital Act, RSO 1937, c 396 s 21.

${ }^{6} \quad$ The Royal Charter of McGill University, 1852; An Act respecting the University of Western Ontario, SO 1967 c. 137 s 41; An Act respecting the charter of the University of Montreal, SQ 14 Geo. VI, 1950, c. $142 \mathrm{~s} 38$; An Act respecting the College of Ottawa, SO 23 Geo. V, c. 106 1933, uOttawa Compilation: Catalogued LE3.O77C4 1938.

7 Bylaws, 2012 s B.4.03.1.b; Constitution and Canons, 2017, cans 19-20 -- "pastoral care" includes the Bishop's traditional right to visit; Canon D1 -- Discipline, 2013 s 2; Canons, 2017, cans A-3.2, F-1.6; Constitution and Canons, can II.9; some right of visitation seems to exist in Anglican customary law: Bentley v Anglican Synod of the Diocese of New Westminster, 2010 CanLII 506 at para 3; Catholic canon law mentions the right Ernest Caparros, Michel Thériault \& Jean Thorn, eds, Code of Canon Law Annotated, 2d ed (Montreal: Wilson \& Lafleur, 2004) cans 381, 392 §2, 396-7.

$8 \quad R v$ Taylor, 2013 NLCA 42 at paras 30-37; Prisons Act $\mathrm{s} 13$; for a fully account of prison visitation in Canada, see Adam P Strömbergsson-DeNora, "Opening the black box: the law of prison visitation", (14 May 2020), online: apstrom.ca $<$ https://apstrom.ca/prison-visitation/>.

$9 \quad$ Law Society Act, SO 1966, c. 207 s 3; Law Society Act s 4. 
have had visitors mentioned in their charters. What can be said conclusively is that every province has or has had a mention of a visitor at some time in an aspect of its law because the office is so pervasive.

This article demonstrates how the office is pervasive with reference to Canadian cases. I am conscious of the disputed nature of the visitor's jurisdiction in Canada - the concept is a dated one, but one that remains in the law reports. No judicial decision has explicitly overruled the office's existence, and where legislatures have suppressed the jurisdiction, they have not explicitly amended the common law (with the possible exception of Alberta). ${ }^{10}$ Suppression of common law jurisdiction must be explicit. ${ }^{11}$ The profession may continue to under-plead visitors' existence, but, as this article shows, Canadian cases have not conclusively overruled the common law and equitable precedents. To be clear, visitors fit within Canada's administrative law framework. They are common law tribunals subject to the prerogative writs: quo warranto, mandamus, certiorari, and prohibition. These writs are typically used in public law; visitors are creatures of private incorporations. Canadian practise confuses the two because the Crown is often visitor to Canadian universities.

This confusion is pointed up in five sections meant to be discursive rather than argumentative or conclusive. The first section reviews the literature on this subject. Section two supplies the English historical cases that define the classic law of visitation. Section three describes the Saskatchewan courts' difficulties handling the office. The section shows that the only Supreme Court case to have seriously considered the law of visitation is limited in its insights because the parties ignored the Court's determination and submitted the dispute to the statutory visitors sitting as arbitrators. Section four reviews the historical use of visitors in other provinces. It shows that the jurisdiction was used in the nineteenth century to assert public control over traditionally private institutions. The fifth and final section reviews cases discussing the visitor and reports of visitors' decisions in the twentieth century. Courts' conflicting decisions in recent decades make the law difficult to apply. While the office might not seem like a persuasive legal argument given some judicial and academic pronouncements, its historical use and more modern judicial commentary show that the precedents remain stare decisis. A discursive piece allows practising counsel, judicial curiosity, and legislative intervention to engage with the jurisdiction. These actors must then draw out visitors' policy merits or definitively suppress the jurisdiction. This paper provides a resource for this endeavour.

\section{OF THE VISITOR}

Universities have been the predominant site of visitation in modern cases, but to the detriment of the office. Popular law admits that there is a certain protected sphere of academic discretion, but it relates that protection to the existence of a contract, of either employment or education, between scholars and their universities. ${ }^{12}$ These legal relationships exists beyond a shadow of a doubt. The visitor's jurisdiction is an additional forum. Where the law runs, the parties subject to a visitor's jurisdiction implicitly agree (and common law requires them) to submit their disputes to the visitor.

In so doing, parties to university disputes acknowledge a tribunal that is removed from the law of the realm, has no docket, need only consider the charity's internal law, and can establish its own procedure. Visitors are, on this view, tribunals subject to a deferential standard of review within their jurisdiction.

10 The visitor was explicitly abolished by The Universities Amendment Act, 1976, SA 1976, c 88; the abolition was maintained up to Universities Act, RSA 1970, c 378 s 7; that abolition was, however, suppressed by the Post-Secondary Learning Act, SA 2003, c. P-19.5 s 153(1)(e),..

11 Ruth Sullivan, Construction of Statutes, 6th ed (Markham, ON: LexisNexis Canada, 2014) at paras 17.5-17.6.

12 Gauthier v Saint-Germain, 2010 ONCA 309, [Gauthier] paras 45-47. 
Their powers resemble those of modern-day administrative tribunals. A visitor's sole adjudicative function, however, is for a single charity. Where they exist, they may provide speedy and tailor-made access to justice that accounts for the peculiarities of the charity's history, location, practices, and members. The visitor of Massey College (Beverley McLachlin), for example, is described by the College as an 'ombudsperson' with power to hear appeals from College decisions. ${ }^{13}$ Solutions crafted by visitors must respect the charity's statutes but are otherwise expressions of the founder's will. Hence the founder's historical right to control the charity to the exclusion of courts. A visitor in New Brunswick, for example, remarked that public policy benefits in certain cases when the Crown is visitor because a visitor offers arms-length oversight when public funds are dispensed. ${ }^{14}$ Charity administrators need not constantly worry about the legal implication of their actions within the charity. The visitor exists as a relief valve in corporations that have static membership (e.g. hospitals, prisons, and universities) where disagreements that arise can be bitter, longstanding, and detrimental to the charity's overall health.

One example obtains in Carleton University $v$ Carleton University Academic Staff Association, ${ }^{15}$ Carleton University's Root Gorelick, a professor and member of the Board of Governors was blocked by the Board from seeking re-election because he refused to sign a code of conduct prohibiting blogging about Board meetings. The union claimed a violation of Gorelick's academic freedom and of his right to participate in university governance; the University claimed that the arbitrator had no jurisdiction over the Board's election procedures because no collective agreement right existed for election to the Board. Arbitrator Nicholas Burkett brought the matter to a full hearing after hearing a preliminary motion because he

would require evidence going to the meaning of academic freedom at this university, to the meaning of self-governance at this university, to the relevance and application of academic freedom to service at this university and, in particular, evidence as to whether one's tenure on the Board of Governors constitutes service under this collective agreement. ${ }^{16}$

The parties' failure to plead the existence of Carleton's visitor - heirs of its founders - meant that the proceeding took place under a labour arbitrator when the dispute properly related to academic freedom, which is a matter of interpreting the University's internal norms. As will be seen, membership in the Board and by-laws relating to Board proceedings are matters within the visitor's traditional ambit. The University's counsel and the Arbitrator may thus benefit from knowledge of the visitor's existence; the union and Professor Gorelick benefit from the existence of an adjudicator who must resolve the dispute if asked to do so without charging arbitrator's fees.

Discussions regarding access to justice omit the law of visitation in favour of fleshing out commonly known tort, contract, or (as above) labour rules. ${ }^{17}$ The law of visitation is left unsaid and under-pled, which effectively erases the visitor's jurisdiction from common law's consciousness. Canada is hardly an exception in this regard. Scholars reviewing New Zealand visitation, for example, suggest that the office

\footnotetext{
"Governance", (2020), online: Massey Coll <https://www.masseycollege.ca/about/governance/>.

Isaac v University of New Brunswick, [1992] 130 NBR (2d) 382 [Isaac] at para 38.

2017 CanLII 73318 (ON LA).

Ibid.

Cynthia L Chewter, "Justice in the University: Legal Avenues for Students" (1994) 3 Dal J Leg Stud 105; Hazel Glenn Beh, "Student Versus University: the university's implied obligations of good faith and fair dealing" (2000) 59 Md Law Rev 43.
} 
of visitor has been done away with: contracts purely regulate university-student relationships. ${ }^{18}$ Another strain of commentary suggests that judicial review of university decisions is the best way to facilitate access to justice for employees and for students. ${ }^{19}$ Some scholars argue a mix of both private and public principles, which is appropriate, but only if the law of visitation is taken into account. ${ }^{20}$

\section{CLASSIC VISITATION}

The classic law of visitors emerges from twelfth-century ecclesiastic principles and is continued after the Henrican and Elizabethan Protestant Reformations, which affected common law. ${ }^{21}$ The essential element of the visitor's jurisdiction is that common law protects visitors from any interference within their domains by external tribunals. ${ }^{22}$ The jurisdiction arises out of the right of an eleemosynary corporation's founder to control the affairs of the charity that they create. The quest to find visitors in each charity requires historical research to determine who first granted funds to the charity. In Carleton University's case, for example, the visitors are most likely the members of the community who first donated to Carleton College in 1942. When these individuals cannot be found, their heirs take up their right to visit. The rule is that visitors accede to their right through the founder's trust vested in the corporation. ${ }^{23}$ The trust allows the founder to define the charity's internal law. ${ }^{24}$ This rule completely removes courts from adjudication of disputes, except for questions of jurisdiction. ${ }^{25}$ Visitors are creatures of private law that settle disputes within the foundation in accordance with the founder's intentions. ${ }^{26}$

Visitors' jurisdictions extend over corporators as a jurisdiction ratione personae and ratione materiae. $^{27}$ The jurisdiction accords with the incorporated charity's status as a community unto itself, one removed (something like a monastic organization) from general society in the pursuit of its goal. In universities, this jurisdiction applies to those who receive the direct benefits of the charity: students, professors, librarians, officers of the university, and any other person connected to the charity's administration. The visitor's subject matter jurisdiction is equally expansive: any question about corporate membership, ${ }^{28}$ the application of rules to members, or the interpretation of an organization's statutes, and the hiring and firing of certain classes of staff, is within the visitor's domain, as are transactions in the

18 Stephen J Kos \& Russell McVeagh, “The View from the Bottom of the Cliff - Enforcement of Legal Rights between Student and University" (1999) 4 Aust N Z J Law Educ 18.

19 Michael J Beloff, "Scholars, Students and Sanctions' - Dismissal and Discipline in the Modern University” (1998) 13 Denning Law J 1.

20 Clive B Lewis, "The Legal Nature of a University and the Student-University Relationship" (1983) 15 Ottawa Law Rev 249; GHL Fridman, "Judicial Intervention into University Affairs" (1973) 21 Chittys LJ 181.

21 Henry Allen Moe, "Notes on the Origin of Philanthropy in Christendom" (1958) 102 Proc Am Philos Soc 371; see also Philips, supra note 3.

22 Saint John's College, supra, note 4.

23 Attorney General v The Deadham School, [1857] 23 Beav 350 (Rolls Crt), 53 Eng Rep 138 (Like any trust, the Court may amend the conditions of the visitor's jurisdiction if it is apparent that the conditions prevailing upon the trust necessitate a change).

24 Philips, supra note 3 at 1297; Whalley \& Evans, supra note 2 at 117-119.

$25 \quad R v$ Dunsheath Ex p Meredith, [1950] 2 All ER 741 (KB); Attorney-General v Magdalen College, Oxford, [1847] 10 Beav 402, 50 Eng Rep 637; Attorney-General v Middleton, [1751] 2 Ves Sen 327 (Ch), 29 Eng Rep 210.

26 Attorney General v Dulwich College, [1841] 4 Beav 255, 49 Eng Rep 337; Green v Rutherford, [1750] 1 Ves Sen 462 (Ch), 27 Eng Rep 1144; The King and Blythe, [1699] 5 Mod 404 (KB), 87 Eng Rep 732; Sutton's Hospital, [1613] 10 Co Rep 1a (KB); 77 Eng Rep 937.

27 Isaac, supra note 14, paras 39-50.

28 The question of membership has always been fraught. See Peiris, supra note 2 at 380. 
organization (such as employment contracts affecting the foundation). ${ }^{29} \mathrm{~A}$ visitor reifies the communal aspect of university life.

The visitor's jurisdiction mirrors a court's, and it does so because the governance of the charity such as a university is so complex that common law recognized the visitor's justice in place of the Crown's. Thus, though a visitor's justice may be at odds with the Queen's courts', theirs was preferred because it ended a dispute between members of the charity. ${ }^{30}$ In modern terms, this rule could create a deferential standard of reviewbecause only the founder's representative embodies the founder's original intention. This principle was so dear to English law that if the founder(s) or its heirs were not mentioned anywhere in the corporation's charter, common law "constructively appoint[ed]" the founder or its heir visitor. ${ }^{31}$

\section{THE UNIVERSITY OF SASKATCHEWAN AND JUDICIAL REVIEW}

The growth of the modern administrative state and its relationship to universities throughout the twentieth century changed these classic assumptions regarding visitation. The state's increasing role throughout the century in spheres of life typically left in the hands of private charity required formal mechanisms of quasi-judicial state control that replicated and eclipsed visitors' functions. Administrative law arrogated the privilege of supervising the welfare state to itself.

The struggle between public administrative law and private property rules plays out in the law of charity. Visitors are a lightning rod in this storm because they replicate administrative law functions. The general concern with administrative law's encroachment in the private law of charitable institutions is described as "the greatest threat to charity independence in the modern age may not be imperium, but dominium". ${ }^{32}$ The state sponsors charity and thereby takes control from the private sphere. This worry forgets the fundament of the visitor's (and charity's) existence. ${ }^{33}$ Dominium is a right of lordship recognized in fief: eleemosynary corporations are ruled by their founders, which creates a kind of estate within the corporation that is reserved to the founder. Imperium, on the other hand, connotes the exercise of supervening power without a necessary right to do so. This latter term is, I think, more worrisome for the effective administration of charity because disputes can last decades if appealed.

The law of visitation suggests that dominium is altogether appropriate if the state has made the first donation to an institution. This legal position is a unique perspective on the Crown's involvement in charity law. Ministers of the Crown already possess statutory rights to control swaths of the charitable sector in ways that are similar to a visitor's jurisdiction. ${ }^{34}$ The common law's recognition of visitors' powers make them an effective shield against the imperium of any foreigner to the charity because they are the exercise the founder's dominium over her or his property. ${ }^{35}$ This very fact, however, runs against the notion of a welfare state unless the Crown itself can be visitor to a charitable corporation. Hence

29 Debate exists in the United Kingdom: Ibid at 381-2; the traditional rules are expressed in Attorney General v Talbot, [1747] 3 Atk 662 (Ch), 26 Eng Rep 1181; Thomson v the University of London, [1864] 10 The Law Times 403 (Ch); Thorne v University of London, [1966] 2 QB 237 (CA); Casson v University of Aston in Birmingham, [1982] 1 All ER 88 (Visitor to the University); Thomas $v$ University of Bradford, [1987] 1 All ER 834 (HL); Page v Hull University Visitor, [1993] 1 All ER 97 (HL).

30 Saint John's College, Cambridge v. Todington, supra note 4 at 199-200.

31 Peiris, supra note 2 at 379; see also The King and Blythe, supra note 26; and Philips v. Bury, supra note 3.

32 Kathryn Chan, "The Co-optation of Charities by Threatened Welfare States" (2015) 40 Queens LJ 561 at 594.

33 Ibid.

34 For e.g. Public Hospitals Act, RSO 1990, c P40, ss 8-9.1, 12(2)-(3); Child, Youth and Family Services Act, SO 2017, c 14 Sched 1, ss 40-46.

35 Chan, supra note 32, 587, although Chan does not connect the visitor with dominium. 
ministers' statutory rights to exercise powers similar to a visitor's, and hence administrative law's recognition of these powers, albeit through a public law lens rather than its traditional private iteration.

Canadian courts default to the centralizing logic of judicial review. As Harry Arthurs (and others) have noted, a court's role in judicial review is a relatively recent exercise of the Crown's imperium. ${ }^{36}$ The Crown's dominium has historically been much more valued by common law because personal rights have been the normal expression of the Crown's power. Where the Crown is implicated in charity, its property has been administered through visitation.

The seminal case for the translation of the Crown's dominium to imperium - the only case of the Supreme Court stating the law of visitation - is King $v$ University of Saskatchewan. ${ }^{37}$ Robert King had been denied his law degree due to poor academic standing. He appealed through the University's process and then sought mandamus in the courts. The University put up the existence of a visitor to show that the Court did not have jurisdiction. The Supreme Court of Canada did not accept the University's argument but found that King had no right to mandamus.

The Court's decision lead to a string of Saskatchewan cases that translate the jurisdiction of a visitor into a jurisdiction subject to full judicial review. A careful look at the conclusion of Robert King's case shows, however, that the immediate effect of the Supreme Court's decision was only to allow the possibility of judicial review. The Court did not prevent the visitor's jurisdiction from being exercised and King eventually only won relief through the informal use of visitatorial powers. Saskatchewan courts have, therefore, taken the Supreme Court's decision much farther than its original ambit - an expression of judicial imperium. Saskatchewan universities have, as a result, been amalgamated into an administrative system that is even more closely associated with managing state power than the visitor's office.

Yet the root of a visitor's jurisdiction remains inviolate in Canadian law: the independence of academic decision-makers is still a value on which courts do not often budge. ${ }^{38}$ The visitor creates the legal tradition of deference to academics operating within their assigned spheres ${ }^{39}$ just as a superintending ecclesiastic officer's jurisdiction in an ecclesiastic dispute should not be upset by the courts (they, too, are visitors) ${ }^{40}$

King $v$ University of Saskatchewan notionally creates space for removing the visitor. The eventual loss of a visitor means that academic disputes cannot be effectively appealed outside of the university unless they go on judicial review. This worrying development deprives the institution's members of the founder's representative's specialized knowledge. It further leaves them at the behest of the academic community without obvious cost-effective recourse. Institutional bias may thus have free reign where the system of

36 Harry W Arthurs, "Rethinking Administrative Law: A Slightly Dicey Business" (1979) 17:1 Osgoode Hall LJ 1; Harry W Arthurs, "Without the Law": Administrative Justice and Legal Pluralism in Nineteenth-Century England (Toronto: University of Toronto Press, 1985); see also Michael Taggart, "Prolegomenon to an Intellectual History of Administrative Law in the Twentieth Century: The Case of John Willis and Canadian Administrative Law" (2005) 43 Osgoode Hall Law J 223; Graeme A Barry, "Spectrum of Possibilities: The Role of the Provincial Superior Courts in the Canadian Administrative State" (2005) 31 Man LJ 149, though these writers do not advocate quite as much for a particular position.

37 King v University of Saskatchewan, [1969] SCR 678, 1969 CarswellSask 38 [King]; although the case of Maurice v Priel, [1989] 1 SCR 1023, 1989 CarswellSask 247, dismisses the office, the Court makes no comment and the dismissal is, at best, obiter.

38 Paine v University of Toronto, [1981] 34 OR (2d) 770 (ON CA), para 20, [1981] OJ No. 3187; Gauthier, supra note 12, paras 45-47; Tran v University of Western Ontario et al, 2016 ONSC 1781, para 81; Al-Bakkal v de Vries et al, 2016 MBQB 45, paras 101-103.

39 Blasser v Royal Institution for the Advancement of Learning, 1985 CarswellQue 88 (QC CA) [Blasser], paras 17-21, 16 Admin LR 298; Yves Ouellette, "Le contrôle judiciare sur l'université" (1970) 48 Can Bar Rev 631 at 636; Re Vanek and Governors of the University of Alberta, [1975] 57 DLR (3d) 595 (AB CA), paras 26-28, 1975 CarswellAlta 53.

40 On this point, see Hart $v$ Roman Catholic Episcopal Corporation of the Diocese of Kingston, 2011 ONCA 728, para 23; Lakeside Colony of Hutterian Brethren v Hofer, [1992] 3 SCR 165 (SCC) at 225, 1992 CarswellMan 138. 
visitation in Saskatchewan formerly permitted the visitor's intervention. The difference is of degrees, with the Court exercising imperium to break down the Crown's formal dominium over the University. ${ }^{41}$ The more appropriate course, and one that could have been adopted in Saskatchewan following King, is to treat the visitor as a condition precedent to judicial review. Failure to adopt this course confirmed the growing narrative that a visitor's private law powers stood in opposition to public law powers and to judicial review.

The Crown's dominium was enunciated from the earliest days of the University of Saskatchewan, which was established in 1883 by the Parliament of Canada; the Governor General was then made visitor. $^{42}$ By 1920, the University was incorporated by a fresh act that made the Lieutenant Governor of the province visitor; ${ }^{43}$ superior court judges in Saskatchewan could be delegated responsibility to visit where such a right vested in the Crown. ${ }^{44}$ This delegation worked through the medieval logic of judicial appointments as justiciars - that is, administrators in the Crown's absence. The advisory role of justices was used to ground jurisdiction not, as in Ontario, in the executive council, but in the judicial branch through which most other disputes were resolved. ${ }^{45}$ In so doing, the jurisdiction became intertwined with the court's equity jurisdiction.

The court's jurisdiction was put to the test in a 1920 visit. In the University of Saskatchewan and MacLaurin ${ }^{46}$ three professors and an officer dismissed by the University appealed to the Crown as visitor, an appeal that was delegated by statutory commission to the Court of King's Bench. Three judges visited on the Crown's behalf to decide the appeal. After hearing arguments, the visitors rejected the appeal. In so doing, they confirmed that visitation applied even to an exercise of statutory authority delegated to a university founded by the legislature: the Crown visits on behalf of the founder, the legislature of which it forms a part.

The Supreme Court's decision in King forty-nine years later marks the clumsy beginnings of Saskatchewan courts eroding the jurisdiction. The University pled the visitor's existence against a law student, Robert King, who, having failed to maintain academic standing, was expelled. He appealed his expulsion to Senate, but, met with continued obstinacy, applied to the courts for mandamus. Justice Johnson declined jurisdiction on the ground that he was not a visitor of the University under the Queen's Bench Act; a royal commission was required from the Lieutenant-Governor before he could visit. ${ }^{47}$ The Court of Appeal assumed jurisdiction on the ground that a public statutory obligation existed that required judicial review. ${ }^{48}$

The Supreme Court departed from MacLaurin and the law of visitation. It created a new stipulation for visitation to force the jurisdiction into conformity with administrative law rules. Mention of a duty in a statute affecting a corporation that provides a public service creates a public obligation that trumps the private law that visitors supervise. ${ }^{49}$ The new interpretation departed from the classic law of visitation. The Court departed from the institutional configuration of the University of Saskatchewan: its legislative

41 Many Lieutenant-Governors of Saskatchewan have themselves been graduates and/or professors of the University, which makes them intimately familiar with the community that they visit.

42 An Act to incorporate the University of Saskatchewan and to authorize the establishment of Colleges within the limits of the Diocese of Saskatchewan, SC 1883, c 47.

43 The University Act, SS 1907, c 24 at 8.

44 The King's Bench Act, RSS 1920, c 39 at 11(3).

45 The jurisdiction of the Court continues: The Queen's Bench Act, SS 1998, c Q-101 at 9(5).

46 [1920] 2 WWR 823 (SK QB), 1920 CarswellSask 80.

47 King v University of Saskatchewan, 1968 CanLII 498 (SK QB), 1968 CarswellSask 52.

481968 CanLII 524 (SK CA), 1968 CarswellSask 60.

$49 \quad$ King, supra note 37. 
history, already supplied the potential to regularize judicial review of university decisions through a royal commission to visit. The visitor was a final court of appeal within the university.

The Court's move in King broke the legislature's intention to maintain royal control over the university, but it did so for naught. After the Supreme Court ruled, on November 25, 1970, the Dean of the College of Law, Roger Carter, wrote to King's counsel to suggest an appeal to the visitor. ${ }^{50}$ This opinion had a ripple effect that expanded until King's lawyer, Henry Rees, wrote to the University Chancellor, John Diefenbaker (then in retirement), and said:

Some time ago I had a letter from Dean Roger Carter suggesting that this is a matter which should be left to the Visitor, to appoint three judges to deal with the matter. I immediately replied stating that I was satisfied that this was not a matter for the Visitor, and indeed this was part of the decision made by the Court of Appeal in the litigation which King carried on; this part was approved by the Supreme Court. ${ }^{51}$

This representation was incorrect. Although no one at the University of Saskatchewan refuted the claim that the University was exercising public power, Dean Carter's suggestion was an offer of clemency. King's case could be referred to the visitor and disposed of quickly. In fact, the visitor, LieutenantGovernor Stephen Worobetz, referred King's case to an ad-hoc university committee, which recommended that King receive the degree. ${ }^{52}$ These recommendations were given effect. The visitor instead referred the university's conclusions to the College of Law. ${ }^{53}$ Dean Carter communicated the Faculty's unwillingness to grant the degree without further investigation on August 9, 1973. ${ }^{54}$ The University's legal counsel also descried the visitor's creation of an ad hoc committee: the statutory authority vested in the visitor could not be delegated, according to counsel, to anyone but judges of Queen's Bench. ${ }^{55}$

The impasse created by the College's refusal and counsel's advice forced a change of tack. King and his lawyer felt themselves vindicated, but they wound up arguing for the visitor's intervention without the visitor intervening. They wished for the personal intervention of the Lieutenant Governor in his capacity as a "good citizen in high office" ${ }^{56}$ Both men re-iterated that any decision regarding King's degree could not be from the visitor because the Supreme Court had created a general rule against visitatorial review. ${ }^{57}$ Both committed an error, and King's lawyer recognized it. ${ }^{58}$ The Court's reasoning only covered King's request for mandamus. The visitor could not be put up to block judicial review; the University's position was that the visitor could still intervene in an internal dispute via Queen's Bench. Even if he recognized this truth, Henry Rees continued to insist on avoiding the visitor, this time by citing MacLaurin:

50 Carter to Rees (Letter, November 25, 1970), Saskatoon, University of Saskatchewan Archives (RG 2009, file 51-12), unless otherwise noted all archival materials are derived from this file number.

51 Rees to Spinks (Letter, December 7, 1972).

52 Spinks to Worowetz (Letter, July 9, 1973).

53 Worobetz to Spinks (Letter, July 12, 1973).

54 Carter to Worobetz (Letter, August 9, 1973).

55 Leslie to Spinks (Letter, August 20, 1973).

56 Rees to Spinks (Letter, February 28, 1973).

57 Rees to Spinks (Letter, August 31, 1973); King to Spinks (Letter, December 18, 1973).

58 Rees to Spinks (Letter, September 4, 1973). 
It is essential for King's success that a formal visitation be avoided. That would mean the Visitor turning the matter over to three Queen's Bench Judges, who would sit as judges, not as examiners. They would be bound to handle the matter on a strictly legal basis. ${ }^{59}$

Rees forgot the discretion so recently exercised by the Lieutenant-Governor. The words of the King's Bench Act in 1920 only provided judges with visitatorial jurisdiction "upon the direction of the Lieutenant Governor". ${ }^{60}$ Judges did not automatically assume the Crown's jurisdiction because the jurisdiction was a personal prerogative akin to a reserve power. Nor were judges bound to make a "strictly legal" determination: the Act specified that judges exercised the Lord Chancellor's power, which is power in equity, when invested with the visitor's jurisdiction. ${ }^{61}$ The Senate, whether conscious of this reality or not, resolved on December 1, 1973, to refer the case to the visitor. ${ }^{62}$

Almost immediately thereafter, Rees demonstrated the fatal misapprehension that he and King had of the visitor's jurisdiction. Rees reiterated that a formal visitation would only examine King's legal right to a degree, to which King did not have a right. The lawyer then said:

This claim ought not to be dealt with on a strict legal basis, but on equitable grounds. [...] This case warrants the kind of language in which early Petitions were addressed to the Lord Chancellor of England, praying that something be done for this man 'for the love of God and in the way of charity', in a case which has gone beyond all application of legal rules."63

Had Rees attended carefully to the King's Bench Act, he would have known that judges sitting as visitors upon a royal commission were in the place of the Lord Chancellor and, thus, heard pleas in equity.

The irony of this case - and the reason why King $v$ University of Saskatchewan has set such an unstable precedent - is that its resolution saw a panel of three judges render a decision. This panel received personal invitations from the University to settle the dispute. The visitor was not involved. Even though the Senate objected on June 1, 1974, to a motion referring the matter to judges, ${ }^{64}$ it consented a year later to this proceeding. ${ }^{65}$ The University was thus visited without being visited. Judges Orest Bendas, Ernest C. Boychuk, ${ }^{66}$ and W.H. Nelson rendered a decision on November 22, 1977. They allowed King to re-write exams in order to obtain his degree. ${ }^{67}$ For all intents and purposes, this decision was a valid exercise of the visitor's and the court's powers even though no formal application had been made. Though it is unclear, in the end, whether King chose to re-write his missing exams, the Supreme Court of Canada's decision was of little practical use. A local tribunal and much negotiation was needed to finally put the matter to rest.

King's pyrrhic victory for was of little consequence to the steady erosion of the visitor's jurisdiction. It is only with retrospect that the Supreme Court's decision in King v University of Saskatchewan can be shown to sit upon shaky foundations. Two years after the judges in King's case rendered a final decision, the visitor was already in the process of being forgotten. In Harelkin $v$ University of Regina, the University

59 Ibid.

60 The King's Bench Act, supra note 44, s 11(3); the same text appears in The Queen's Bench Act, supra note 45, s 12(3).

61 The King's Bench Act, supra note 44, s 11(3).

62 Spinks to Rees (Letter, December 6, 1973).

63 Rees to Spinks (Letter, December 10, 1973).

64 Senate Sitting (Minutes of Meeting, June 1, 1974).

65 Recommendations (Report, April 26, 1975).

66 Boychuk was a supporter of King's receiving the degree: Rees to Spinks (Letter, December 20, 1973).

67 Senate Sitting, supra note 64. 
of Regina's visitor was not relied upon in defense of university regulations even though the Supreme Court noticed the jurisdiction. ${ }^{68}$

The Saskatchewan visitor languishes for a time until two other instances of visitation arise in relation to one Dr. Pearlman. The first incident is an unreported personal visit from the Lieutenant-Governor, Dr. Sylvia Fedoruk. The second incident involved the Court of Appeal's judicial review of a Queen's Bench visitor's decision. ${ }^{69}$ The visitor had restored Pearlman, a medical resident, to his position in the College of Medicine after a number of legal proceedings. The University took the matter on judicial review, and the Court of Appeal chose to apply an administrative law analysis in the face of other Canadian decisions upholding the law of visitation:

The University was created by, and exists pursuant to, a public statute. Its central objective is to provide a public service in the form of education and research. It is financed substantially by way of government funds. All of this, in combination, puts the University on a different footing than the ancient Oxford and Cambridge Colleges [...] The thoroughly public character of the University of Saskatchewan suggests, in my view, that the substance of the Visitor's actions should be open to a measure of scrutiny through the courts. ${ }^{70}$

The Court extended the reasoning in King to its logical conclusion. The public authority granted to a visitor by its statutory creation was to bring the officer wholly under the Canadian administrative law regime. ${ }^{71}$ The visitor could be controlled through the prerogative writs just like any other statutory board or tribunal. ${ }^{72}$

The jurisdiction was finally suppressed in 2009 after the Court of Appeal in Mycyk v University of Saskatchewan granted judicial review of a visitor's decision. In so doing, the Court of Appeal acknowledged that "the nature of the office and its history dictate an attitude of deference, but not in matters of jurisdiction". ${ }^{73}$ The question then before the court was traditional in administrative law: was the visitor's decision reasonable and within the bounds of its jurisdiction? The Court found that it was in some respects, not in others. ${ }^{74}$ Administrative law concerns thus came full circle, and the legislature did away with mention of a visitor with the University of Saskatchewan Amendment Act, 2009 and The University of Regina Amendment Act, $2011 .{ }^{75}$ The University of Saskatchewan heralded the end of the visitor's long run by replicating administrative law terms that it knew only too well: "the rules for judicial review have developed substantially, [...] with the Court of Queen's Bench overseeing administrative tribunals." "76 The effect of this expression and the Saskatchewan courts' disposition toward the visitor was to move the University into the full ambit of judicial review on the grounds that the University was a statutory decision-maker, which was the rationale used by the Supreme Court in King to assume jurisdiction even as the Court in King did not preclude the visitor's authority. The resulting view of the visitor in Saskatchewan was that it was a useless appendage. The universities did not appreciate the

\footnotetext{
68 [1979] 2 SCR 561, paras 149-151, 1979 CarswellSask 79.

69 This decision is found at 2005 SKQB 372.

70 Pearlman v University of Saskatchewan (College of Medicine), 2006 SKCA 105, para 39.

71 Ibid, para 43.

72 Ibid, paras 44, 50.

73 Mycyk v University of Saskatchewan, 2009 SKCA 71, para 45.

74 Ibid, paras 90, 119, 120.

75 The University of Saskatchewan Amendment Act, 2009, SS 2009, c 3, s 4; The University of Regina Amendment Act, 2011, SS 2011, c 20.

76 Office of Communication, “"Visitor' left out in act revisions”, (17 July 2009), online: Campus News $<$ https://ocnarchives.usask.ca/09-july-17/11.php>.
} 
Governor's interference and litigants and courts alike did not necessarily view the visitor as a legitimate tribunal.

\section{HISTORICAL APPLICATION}

The University of Saskatchewan's relatively late beginnings in Canadian university history drew on eastern and central Canadian antecedents to ground its law of visitation. Mid-to-late-nineteenth-century cases of visitation confirm that the jurisdiction was commonly used. The speed of communication made visitors attractive. Local officials could, by commission or by personal right, close disputes in local charities by exercising the founder's rights. The Crown and parliaments deployed the jurisdiction in this manner to ensure its dominium in fledgling provinces where individual charity could not sustain universities. The Crown supervised the institutions to which it granted university powers, thus giving government control over systems of higher education that were typically highly sectarian.

A more modern example is the similar system that continued in Quebec elementary and secondary schools until 1988, where the Minister of Education was visitor to every school, most likely to ensure that the curriculum was maintained. ${ }^{77}$ The Province of Canada most notably granted university powers to universities other than Toronto and $\mathrm{McGill}^{78}$ with the inclusion of the Crown as visitor. ${ }^{79}$ It did so fully conscious of its ability to use the office, as was first made apparent with the visitation of the University of Toronto in 1849 and again in 1860. These visits demonstrate the Crown's use of reforming power as an exercise of dominium.

My analysis begins, however, with a rehearsal of the classic English rules of visitation and their slight modification as regards King's College, Windsor (now Halifax), the oldest chartered university in Canada. The Archbishop of Canterbury intervened in a visitatorial capacity to annul statutes in 1806 . In a related incident, Dr. William Cochran, the College's acting president, is reported to have requested the visitor's intervention as early as 1805; the case of Re Wilson, which appears in 1885, fleshes the jurisdiction out further.

The Archbishop's intervention is a rare example of a visitor visiting a visitor, which is suggestive of the complexity of these domestic tribunals. The bare bones for King's were established in 1789 by legislative charter: no visitor was mentioned. ${ }^{80}$ A royal charter supplemented the Act in 1802 and appointed the bishop of Nova Scotia visitor. The Archbishop of Canterbury, the bishop's ecclesiastic visitor, was made patron. In 1803, the Oxford men who controlled King's Board of Governors gave it statutes that obliged students to sign the thirty-nine articles of the Church of England. ${ }^{81}$ Nova Scotia's

77 Education Act, RSQ 1977, c I-14 [Education Act], s 20, cf. CQLR, c I-13.3, s 459.6; Ouellette, supra note 39 at 648, speaks to the analogy between the Minister's role under the Education Act and a potential role for the Minister where no visitor is formally appointed; a further holograph of the visitor's office exists in Education Act, RSO 1990, c E.2, s 50.

78 Although McGill had the Governor General as visitor by 1852. See: McGill University, Montreal, extracts from the will of the founder, Early Canadiana Online 09481 (Montreal: J. Lovell, 1883) at 16, 20, 22.

79 An Act to Amend the Acts Incorporating "The College of Ottawa," and to grant certain privileges to the said college, S Prov C 1866 (29-30 Vict), c 135 [1866 Charter], s 14; An Act to amend the Acts respecting the College of Regiopolis, and to erect the same into an University, S Prov C 1866 (29-30 Vict), c 133, s 5; Queen's University did not have a visitor in the Royal Charter granted by Victoria in 1841, but it pled the existence of its visitor in the case of Weir $v$ Matheison, for which we have a complete print edition of all pleadings and evidence: In the Court of Error and Appeal for Upper Canada, Early Canadiana Online 63239 (Toronto: Globe, 1865).

80 An Act for founding, establishing and maintaining, a College in this Province, SNS 1789, c 4.

81 The statutes, rules and ordinances, of the University of King's College, at Windsor, in the province of Nova-Scotia, Early Canadiana Online 88952 (Halifax: John Howe, 1803) at 31. 
diverse religious population rebelled at the suggestion, as did the College's visitor, Anglican Bishop Charles Inglis. ${ }^{82} \mathrm{He}$ did not, however, press his claim. Inglis instead wrote the Archbishop of Canterbury, his metropolitan and visitor, ${ }^{83}$ to suggest that the patron exercise his right in the royal charter to "signify his disapprobation" of the statutes within three years of their adoption. ${ }^{84}$ Whether it was this letter or the Attorney General of Nova Scotia's discussion with the Archbishop that finally spurred the use of archepiscopal power is unclear. ${ }^{85}$ The outcome is that the Archbishop exercised his power to impose statutes upon the College, thus ending the dispute. ${ }^{86}$

Dr. Cochran's use of the visitor was collateral to the problem with statutes. He invoked his right as acting president to be visited against the Board of Governors, who sought to deprive him of his rooms at the College. One reason for the Board's dislike of Cochran was his refusal to accept the statutes because he himself would not subscribe to the thirty-nine articles. The Governors ordered Cochran out of his rooms late in 1804. He refused the Governors' order and wrote : "if it be alleged that I have transgressed [the new statutes], or misbehaved in any other manner, I demand that a Visitation be held in the College to try the truth of such allegations, and then I will be ready to make the contrary appear". ${ }^{87}$ This classic right to be visited in a dispute between the acting president and the Board demonstrated the power of visitation: the Bishop of Nova Scotia would have entered the fray. Given the Bishop's misgivings about the statutes in 1804-5, it is likely that Dr. Cochran would have won. The Governors settled the matter with Cochran shortly thereafter. ${ }^{88}$

Re Wilson, the 1885 case that Robert King relied upon in his submissions to the University of Saskatchewan, ${ }^{89}$ departs from this classic view of visitation by creating a distinction between universities and colleges incorporated with public funds, with a public mission, and private incorporations. ${ }^{90}$ This distinction relied upon the King's 1853 legislative charter. ${ }^{91}$ This charter created a second corporation, the University, that could not be said to be a charity in the way colleges were charities. The governors of the College and of the university were identical; the visitor was used to tie the two corporations together.

Wilson traces a King's College professor's successful appeal from his dismissal by the University's Board of Governors after he had made libellous claims in a Halifax newspaper. These claims came (again) in the wake of a public dispute between members of the faculty and governors that, in 1884, saw the students burn the College president in effigy, which lent the judicial proceeding in 1885 some notoriety. ${ }^{92}$ The University pled the existence of its visitor, the Anglican Bishop of Nova Scotia, against the professor's plea in mandamus. The professor alleged denial of natural justice: no notice of the Board of Governors' meeting to decide his dismissal had been provided. The court made out a violation of Wilson's right audi alteram partem in a 3-2 majority. It decided further that the visitor's jurisdiction did not insulate the

82 Judith Fingard, The Anglican Design in Loyalist Nova Scotia 1783-1816 (London: S.P.C.K., 1972) at 152-3.

83 John Colt \& William Glover vers Richard Evesque de Coventry \& Lichfield, [1612] Moo KB 1262,72 Eng Rep 982 [Colt $]$.

$84 \quad$ Supra note 81 at 3 , see also 7.

85 Fingard, supra note 82 at 153.

86 Ibid; Henry Youle Hind, The University of King's College, Windsor, Nova Scotia, 1790-1890 (New York: The Church Review Company, 1890) at 40-43, 46.

87 Hind, supra note 86 at 39 , for a full account of this episode, consult 32-46.

88 Ibid.

89 King to Spinks, supra, note 57, p. 11.

90 Re. Wilson [1885] 18 NSR 180.

91 An Act to Incorporate the Governors of King s College, Windsor, and to repeal the Act for founding, establishing, and maintaining a College in this Province., SNS 1853, c 66 [Governors King s College].

92 Henry Roper, “Aspects of The History of a Loyalist College: King's College, Windsor and Nova Scotian Higher Education in the Nineteenth Century" (1991) 60 Angl Episcop Hist 443 at 453. 
decision to dismiss: the Bishop was also president of the University's Board of Governors, and his colleagues were all members of the Crown's executive or otherwise appointed by the Crown. ${ }^{93}$

Justice John Thompson (later Prime Minister) identified two corporations at issue in the case, one to which visitation attached and another in which the visitor was a corporator. This distinction allowed the court to assert its jurisdiction because the visitor, if allowed to intervene, was set to visit himself. Formal control came to naught, however, when the visitor was pleaded because of that additional corporate layer that represented the government's desire to control the College. Justice Thompson ably distinguished between the usual sort of college, one founded in England to sustain its members, and King's public foundation:

How does the case stand with this College? It has no founder, in the sense of the English law. It was a public corporation, established by the Legislature of the Province. It was incorporated by a public statute in 1789 . I say a public statute, because the statute has all the features, and complies with the usual tests by which public acts are distinguished, -dealing with the public revenue, reciting that it is for public utility, etc. ${ }^{94}$

The legislative claim to found the college for "public utility" altered the law of visitation by inviting the Court's scrutiny of the Board of Governors because the Board was, with the aid of the formally appointed visitor, enacting the Crown's will over the College:

This corporation then, of governors, not being situated at all like the Fellows of an English University, not being the objects of the Founder's bounty, but the administrators of that bounty, being in fact put in the Founder's place, to administer the bounty, and to make statutes as to all matters respecting the college, made this statute which provides that a professor is liable to be removed for certain causes, if nine of their number vote for his removal, and appointed Professor Wilson subject to it and dismissed him under it. ${ }^{95}$

The Bishop could not be invoked to defend the Board's action. Such a defense was tantamount to the Bishop visiting himself. ${ }^{96}$ This statement of the visitor's jurisdiction allowed the Court to enter into the University's affairs, such as the decision of the Governors (not the fellows of the College) to dismiss a professor. Justice Thompson, however, forgot the royal charter's grant in favour of the Archbishop of Canterbury: this priest could visit the Bishop of Nova Scotia, which provided a stand-in when the Bishop was incapable. This point notwithstanding, the government's control over the College was not complete. The Court created a distinction between the public designs expressed by the legislator and the private intentions of a traditional founder.

Justice Weatherbe, though writing in dissent, further explained how a visitor (whether the Crown or another individual) appointed by statute was tied to the legislature. The absence of the private charity essential to visitation deprived King's College of the visitor's protection against judicial review unless the

93 Governors King s College, supra note 91.

94 Re. Wilson, supra note 90 at 193-4; note the similarities with the way in which the Supreme Court expresses itself in Eldridge v British Columbia (Attorney General), [1997] 3 SCR 624 (SCC), para 43, 1997 CarswellBC 1939.

95 Re. Wilson, supra note 90 at 196-7.

96 Ibid at 198-9; though this case is not cited by Thompson J, the principle is shown to be of far older extraction: Colt, supra note 83 at 983, where it is said: the bishop of a diocese "poit estre visit per le Metropolitaine coment que il ne poit visiter luy mesme" [the Metropolitan may visit so that he does not visit himself]. 
legislature's mention of a visitor in its charter of 1853 could stand for more than "an empty name". 97 Justice Weatherbe innovated: he identified King's College's founder as the legislature itself, thus giving the Bishop of Nova Scotia delegated legislative authority to supervise the College. The public nature of the foundation came full circle. A common law rule bolstered legislative intent. ${ }^{98}$ The result for Weatherbe was that the Court could renounce jurisdiction in favour of the Bishop because, citing Lord Mansfield in Saint John's College v Todington, the visitor "is appointed and made absolute upon this principle, 'that, in these societies, error of judgment, the chance of partiality, or injustice, is a less evil than the duration of contention"".99 This principle remains the essential character of the visitor's jurisdiction.

The earlier royal visit at the University of Toronto explains the Canadian roots of the majority and minority analyses in Wilson. The University of Toronto was structured in 1849 on the same lines as King's College, with a university corporation lording over a university college. This structure came about as a result of mismanagement in the $1830 \mathrm{~s}$, when the college was created by royal charter. The legislature intervened through the University Act, $1849^{100}$ to separate the university from the college. This act also altered the Crown's position at the University from that of chancellor to visitor and commanded the Crown to appoint a commission of five visitors to inquire into the differences between the university and the professors incorporated in the college. ${ }^{101} \mathrm{~A}$ similar arrangement existed for King's College, New Brunswick, which was visited by legislative commissioners in $1851 .{ }^{102}$

The effect of this exercise of royal authority over the University of Toronto in 1849, however, did not fully manifest itself until a second commission was appointed in 1860, this time by the Attorney General, John A. MacDonald. This commission responded to Methodist and other religious groups' concerns with the way in which the University of Toronto was structured to exclude religious observance in affiliated colleges. ${ }^{103}$ This structure fragmented Canada West's system of higher education. Independent colleges taught curricula apart from the University's power to grant degrees.

The public nature of the problem in 1860 influenced Macdonald's commission to the visitors such that the commission was in point of law and fact a "royal" one as we understand it today. The visitors reported to Governor General the Lord Monck on May 29, 1862. They defined their jurisdiction with reference to what appears to be a common legal presumption: "having the full Visitatorial powers of Your Excellency committed to them, the Commissioners gave a wide range to their enquiries". ${ }^{104}$ Without entering into the details of those inquiries, the Commissioners made sweeping recommendations to the Governor for legislative reform of the University and its College. They further reecommended transferring administration of the University's endowment to the government. These recommendations were

97 Re. Wilson, supra note 90 at 204.

98 Ibid at 209.

99 Supra, note 4 at 199-200.

100 An Act to Amend the Charter of the University Established at Toronto and to provide for the more satisfactory government of the said university, and other purposes connected with the same, etcetra, S Prov C 1849 (12 Vict), c 82.

101 Ibid, ss 47-49.

102 WO Raymond, The Genesis of the University of New Brunswick, Early Canadiana Online 79546 (St. John: Publisher not identified, 1919) at 22-23; early statutes of King's College framed the Anglican Bishop of Nova Scotia (who had jurisdiction over the archdeaconry of New Brunswick) the Crown's delegate as visitor and reserved the Crown's right of disallowance. In this scheme, the Lieutenant-Governor was only the Chancellor King's College, The statutes, rules and ordinances, of the University of King's College, at Fredericton, in the province of New-Brunswick (Fredericton, N.B: J. Simpson, 1830).

103 J George Hodgins, Documentary History of Education in Upper Canada (28v., Toronto: Warwick Bros. \& Rutter, 18941910) at 16:21-22, 66-75.

104 Ibid at 17:59. 
strenuously opposed by the University senate, which voted five resolutions against the Commissioners on March 5, 1863. The first of these bears mentioning:

That it is of the last importance to the Province to maintain and augment the efficiency of the Provincial University and College, that the Endowment should be preserved intact, and the Revenue strictly applied, so far as necessary, in the furtherance of this object, and that this Meeting regrets that the Government Commissioners in their recent Report should lend themselves to a scheme involving the spoliation of the Endowment. ${ }^{105}$

My allusion to a modern royal commission at least circumstantially bears out with the Senate's mention of "Government Commissioners". The Governor General was colloquially (and constitutionally) understood as a metaphor for government; the Crown's exercise of power in this case came about because Parliament had reserved jurisdiction to the Crown. The reservation worked in much the same way as Justice Thompson's later description of King's College. The government possessed absolute control that was identified by university administrators in 1863 .

Such control was again exerted by the Ontario government after Confederation in 1886 at the University of Western Ontario. The Crown disallowed Western's Senate statute creating a school of law, the London Law School. The disallowance came on the heels of the creation of a conventional law studies program that, at the time, mimicked the Law Society's requirements. ${ }^{106}$ Received wisdom is that the visitor acceded to the Law Society's statutory monopoly on legal education and disallowed the statute. ${ }^{107}$ A closer look at executive council correspondence returned to Parliament, however, shows that the Crown was advised on a technical point. The Minister of Education, George William Ross, advised the Governor on March 5, 1886, that

in recommending the disallowance of the said Statute, the undersigned does not wish to be understood as opposed to the establishment of the said Law Faculty, with such powers as may be necessary for its efficiency and usefulness, but it is obvious such powers must be exercised in accordance with the Act by virtue of which the University exists. ${ }^{108}$

The University's charter required the Senate exercise ultimate control over all educational decisions. The Faculty was meant to exist apart from this regime. The rub was not infringement of the law society's monopoly; Ross determined that the law school had to be subject to the University Senate's power.

Western's case builds on Justice Thompson's decision in Wilson. The Crown's common law power as visitor was exercised on the recommendation of Council. This typical formula frames the Crown-in-right of Ontario as an agent of the founder similar to the majority's description in Wilson's case. The Crown inspects the institution at the behest of the legislature, thus ensuring the legislature's intention as though it were a private person operating under an endowment.

105 Ibid at 17:133.

106 Senate Meeting and Statute (Minutes of Meeting, August 2, 1886), London, Western University Archives (File AFC 71); cf. Law Society of Upper Canada, Rules of the Law Society of Upper Canada : passed in convocation, Hilary term, 44 Victoria, and approved by the visitors of the society (Toronto: Rowsell \& Hutchison, 1881) at 50-53, and note that the Law Society acknowledges the utility of its visitors in the title and again in the list of members .

107 Belinda A Beaton \& Andrew Mcintosh, Western University, online ed (Toronto: Historica Canada, 2018).

108 Legislature of Ontario, Sessional Papers (Toronto: Queen’s Printer, 1886), No. 86 at 11. 
These examples of visitation and judicial approaches to visitation demonstrate the Crown's involvement with universities from a fairly early moment in Canadian judicial history. The visitor's jurisdiction in eastern and central Canada speaks to the government's use of visitors to extend dominium over charitable corporations. This view is tempered by the understanding that visitation remained an exercise of the Crown's right (like any of its subjects) to be charitable. Courts could intervene in the Crown's charity, but they did so because the Crown had set up circuitous structures. Legislative and royal benevolence were historically acknowledged as a fact of life very similar to the medieval English origins of power. The Crown visited through its executive council; courts and their imperium remained dissociated from visitors to ensure speedy and efficient resolution of disputes.

\section{MODERN APPROACH}

This historical acknowledgment of the classic approach to visitation continues somewhat into modern Canadian law. The traditional view of visitors was affirmed in Quebec, New Brunswick, and Ontario even after King. Where a visitor exists, its presence could be a condition precedent to judicial review. Visitors thus continue to serve their core function as a domestic tribunal overseeing the trust vested in a charitable corporation. New Brunswick cases show the best of the visitor's jurisdiction, even though the New Brunswick legislature has suppressed the office.

Modern cases also show that appellate courts are reticent to confirm the jurisdiction because they view it as an affront to administrative law and to other private law solutions to university disputes. The policy choice that appellate courts have made in this regard is the greatest impediment to the jurisdiction's existence. Recent examples of its utility for universities as well as employees and students show that courts of appeal do a substantial injustice to parties by not requiring them to settle internal disputes where the common law has always commanded that they be settled. The courts' view of visitors adopts the narrative from King: visitors oppose public law remedies. This unfortunate turn forgets the principle that courts ought not intervene in university affairs until all internal appeals have been exhausted - a principle that exists in perfect harmony with the law of visitation.

One case contemporary with King but predating it by a year is the Quebec Court of Appeal's decision in Fekete $v$ Royal Institution for the Advancement of Learning (i.e. McGill University). This decision begins appellate courts' pattern of declining to deal with substantive issues relating to visitation in favour of other grounds. ${ }^{109}$ A student published a libel in the McGill Daily, a campus newspaper. The University sought to discipline the student for his conduct; the student sought judicial review. At trial, the University pled the existence of a visitor, but the judge gave the plea no effect. The trial and the Court of Appeal judges focused instead on the interpretation of articles 33 and 846-850 of the Code of Civil Procedure, which created a right similar to certiorari for removal of a case before a lower court to the Superior Court. ${ }^{110}$ The Court held that it need not consider the visitor's jurisdiction because the right claimed to flow from the Code of Civil Procedure which did not exist for appeals from private decision-makers, such as McGill's discipline committee. Without citing Fekete or King, the Quebec Court of Appeal again eschewed consideration of Laval University's visitor in Langlois v Laval University. ${ }^{111}$

It is only in 1985, in the case of Blasser v McGill, that the Quebec Court of Appeal acknowledged the University's visitor, but it was careful to connect the visitor's jurisdiction with the wider principle that

109 [1968] 2 DLR (3d) 129 (QC CA).

110 Ibid at $130-1$.

11147 DLR (3d) 674 (QC CA), 1973 CarswellQue 242. 
universities should be allowed to govern themselves independently. ${ }^{112}$ In so doing, Blasser confirmed that a visitor has jurisdiction even over a contractual obligation between student and university because that obligation is subsumed in the institution's academic regulations.

Another case occurred in Forestell v University of New Brunswick, where the visitor was successfully pled and its subsequent decision was reported. A student member of the Board of Governors was amoved by the Board for improper conduct. She sought judicial review but was denied when the University pled the existence of its visitor. ${ }^{113}$ She applied to the visitor, whereupon she was restored to the Board because the Board had acted unfairly. ${ }^{114}$ The Board's action was deemed unfair and the issue was resolved without going through judicial review. The student had a right to be restored that could be addressed by writing to the Lieutenant-Governor sitting in appeal as an officer connected to but outside of the University.

The University of New Brunswick was again visited when Thomas Isaac, the probationary don of a university residence, alleged that he was dismissed unfairly. He applied to the Lieutenant-Governor as visitor, whereupon a commissioner was appointed to hear the matter. The commissioner found that the Board of Governors improperly delegated its power to dismiss employees. He ordered payment of damages in the form of lost wages. In so doing, the commissioner restated the dissenting opinion in $R e$ Wilson:

The continuation of the Office of the Visitor by a public statute, for a publicly incorporated educational institution, emphasizes the unique nature of the University of New Brunswick. The University has the full power and authority to promote and carry out the work of a university but, as a public institution, it is subject to the scrutiny of the Legislature responsible for its continued existence. The Office of the Visitor allows the University to maintain its independence, without undue public interference, while providing for public accountability. ${ }^{115}$

While this argument hews to an administrative law approach to the office (as does publishing the visitor's decisions in the law reports), the logic preserves the Crown's dominium, and it does so explicitly in the public interest. The visitor relieves courts of initial jurisdiction over academic disputes. The legislature of New Brunswick has, however, since suppressed the visitor's statutory jurisdiction. ${ }^{116}$

The issue of legislative suppression is illustrated by a pair of Alberta cases that resulted in an additional rule: legislative suppression of the visitor is tantamount to the elimination of the visitor. With the visitor gone, the courts revert to the law of contracts to determine employment disputes. Alberta's Universities Act previously established visitors at the University of Alberta and at the University of Calgary by section 5, which read: "The Lieutenant Governor is the Visitor of each university with authority to do all those acts which pertains to Visitors." ${ }^{117}$ In Vanek v University of Alberta, ${ }^{118}$ the Court applied King to determine that the Crown was visitor and, as such, visited over the regulations established under the statute. Unlike King, where the rule at issue was found in legislation, no public duty existed where a regulation was

112 Blasser, supra note 39, paras 26, 34-40.

113 Forestell v University of New Brunswick, [1987] NBJ No. 1012 (NBQB), 1987 CarswellNB 177.

114 Forestell v University of New Brunswick, [1988] NBJ No. 443 (Visitor of the University of New Brunswick), 1988 CarswellNB 138.

115 Isaac, supra note 14, para 30.

116 University of New Brunswick Act, SNB 1984, c 40, s 17, suppressed by SNB 1993, c 14, ss. 2-3.

117 Universities Act, RSA 1970, с 378.

118 Supra note 39. 
privately promulgated. A professor who had been denied tenure at the University had no recourse before the courts.

This decision was applied later that same year to deny judicial review of a tenure decision in McWhirter $v$ University of Alberta. The trial judge refused jurisdiction. ${ }^{119}$ On appeal, the Court of Appeal noticed that the legislature had changed the common law of Alberta in 1976 to explicitly "abolish" university visitors. ${ }^{120}$ It returned the case to the trial judge for re-trial, whereupon the judge heard the case in contracts. ${ }^{121}$ As with any legislative enactment, the use of particular words accomplished its effect.

Less clear is the 1975 case of Polten and Governing Council of the University of Toronto et. al., ${ }^{122}$ where the visitor was found to have been implicitly suppressed. Polten indirectly applied King to determine whether any public duty existed for the Attorney General, as the Crown-in-right-of-Ontario's legal advisor, to visit. Here again, the Court used the public-facing nature of the University as proof that it could intercede because "the university has been entrusted with the higher education of a large number of the citizens of this Province. This is a public responsibility that should be subject to some measure of judicial control."123 After claiming jurisdiction, the Court discarded the existence of a visitor at the University of Toronto on the basis of legislative omission. In 1906, when the University's charter was reenacted, the Crown's old authority to visit that drew its origins from the 1849 Act was superseded in 1906 by the words:

All the powers over, in respect of, or in relation to the University and University College and each of them which now are or may be exercised by the Lieutenant-Governor, save only such powers as are by this Act expressly reserved to the Lieutenant-Governor in Council, are hereby, subject to the provisions of this Act, vested in the Board. ${ }^{124}$

The Court thus held that the visitor's jurisdiction has been permanently ceded by the Crown because the powers were ceded to the University's Board of Governors in 1906. As such, no powers existed in 1975 that the Crown could be compelled to exercise. ${ }^{125}$

Polten was overruled twenty years later in Wong $v$ University of Toronto, but the Court of Appeal again did not address the question of visitors: the law remained unsettled. A doctoral student in psychology had a conflict with her thesis supervisor. The supervisor resigned his role as supervisor; the candidate appealed the supervisor's resignation. The appeals committee found that there was no jurisdiction to deal with the matter because a replacement supervisor had been found and no academic regulation spoke to the issue. However the supervisor's appointment was conditional upon the student withdrawing all allegations against the University and against her former supervisor. The student launched an action in tort and breach of contract. The University countered with an application for summary judgment and put up the existence of "visitatorial powers in law which preclude the interference of the courts in academic disputes". ${ }^{126}$ The University's subsidiary argument was that the Court should decline to interfere in academic matters except

119 [1975] 62 DLR (3d) 684 (ABSC TD).

120 The Universities Amendment Act, 1976, SA 1976, c 88, s 2.

121 [1977] 80 DLR (3d) 609 (ABSC TD), 1977 CarswellAlta 464; rev'd on other grounds: [1979] 103 DLR (3d) 255 (ABCA), 1979 CarswellAlta 403.

122 [1975] 59 (3d) DLR 197 (ONSC, Div Crt), 1975 CarswellOnt 411 [Polten].

123 Ibid at 212.

124 University of Toronto Act, 1906, c 55, s 38.

125 Polten, supra note 122 at 220.

126 Wong v University of Toronto, 1990 CanLII 8102 (ONDC) [Wong] para 10, 1990 CarswellOnt 825. 
on judicial review. The trial judge accepted both of the University's arguments and tarried long on the visitor's existence.

In so doing, the Court confirmed a point central to the doctrine of visitation, at least as regards universities: academic matters are protected from judicial review as a residuary right flowing from the doctrine. Polten was distinguished:

His Lordship's comments are made in the context of the claim for relief against the Attorney-General of Ontario for an order declaring that the applicant had a right to have a royal visitor appointed by the Attorney-General, and an order requiring the AttorneyGeneral to appoint a royal visitor. In the context of the prayer for relief before him, I take his conclusion to mean that visitatorial powers do not exist only in so far as royal prerogative is concerned. Put another way, Her Majesty does not continue to enjoy and hold visitatorial powers as they existed at the time of the Charter of the University: visitatorial powers by statute were vested in the governing body of the University ("ceded", to use Justice Weatherston's language). Once granted or surrendered to that body, as His Lordship held, those powers cannot be reclaimed or revert to the Crown except by statute under the principle of the supremacy of Parliament. ${ }^{127}$

The Board of Governors was made visitor in 1906 when the legislature vested all of the Crown's powers in the Board. This power was continued in subsequent iterations of the University's charter. ${ }^{128}$ In this way, the rule in Wilson's case might well have been made to apply: the Board could not visit itself, but it could visit all inferior jurisdictions within the University. Hence the Court's rule in Wong that "the very essence of a university as a place of learning is the relationship between professors and students. Visitatorial powers include the regulation of that relationship and the power to provide remedies where appropriate". ${ }^{129}$ The Court indicated that it could assume jurisdiction if a visitor did not exist, but declined to do so if a visitor did not exist because all the internal processes at the University had not been exhausted. ${ }^{130}$ The Court of Appeal declined to rule on visitatorial powers and contented itself with the trial court's result: internal processes must be exhausted before a court intervenes in an academic matter. ${ }^{131}$ Without explicitly overruling the trial court in Wong, the Court of Appeal left the law as it was in Ontario. The implication of Wong's trial decision is that visitors whose powers disappear from founding statutes may still exist. Only a careful reading of the statute can determine whether the powers have been definitively suppressed within the statute and at common law.

Wong raises a further question, for suppression of the jurisdiction's existence in a statute does not necessarily change a corporation's right to a visitor. The legislature's decision to remove mention of the jurisdiction's existence in the founding statute has been theorized to remove the jurisdiction altogether, but the legislature does not amend common law in removing one mention of the office in a single statute. The traditional rule where common law constructively appoints a visitor might flow in to fill the legislative void. Such an interpretation fits with the policy enunciated at trial in Wong and confirmed by centuries of

Ibid, para 33.

128 An Act respecting the University of Toronto, RSO 1914, c 279, s 30; The University of Toronto Act, 1947, SO 1947, c 112, s 41; The University of Toronto Act, 1971, SO 1971, c 56, s 2(14).

129 Wong, supra note 126, para 46.

$130 \mathrm{Ibid}$, paras 53-7.

131 Wong v University of Toronto [1992] OJ No. 3608 (ONCA) 1992 CarswellOnt 916. 
use. Visitors are suited to adjudicate university disputes because they have the authority to settle legal issues as well as academic ones.

\section{CONCLUSION}

Access to justice requires timely and cost-effective approaches to dispute resolution. Visitors fulfill these objectives while providing specialized expertise that cannot be found in the courts. Indeed, I have shown how this administrative law argument has been retained by courts even where the visitor's jurisdiction has been disregarded.

The obvious tension between administrative law arguments and a right of visitation is that visitors exist due to private law. Courts and scholars have not yet squared this circle. More work will need to be done on the private law roots of the visitor's jurisdiction to show how it is created, the logic that underpins the jurisdiction, and how that logic can be put up against administrative law norms. The Supreme Court in King had the opportunity to conduct such an analysis, but it held off on this point, perhaps due to the discomfort associated with admitting a private jurisdiction without any statutory direction.

Critically, the presence of the visitor helps to relieve the courts in the same way that administrative tribunals help settle disputes without clogging a court's docket. The visitor's specialized jurisdiction thus fits with a wider judicial preoccupation to reduce disputes coming before the courts. It is no wonder, then, that in Lam v University of Western Ontario, the University of Western Ontario pled a summary dismissal successfully against a student's action in breach of contract and breach of fiduciary duty. The doctoral candidate complained that the University had not correctly replaced his supervisor after the supervisor's untimely death. The trial judge dismissed the claim because "as a matter of law it should have been brought as a complaint to Western, whose decision would have been subject to judicial review". ${ }^{132}$ The Court of Appeal, however, overturned this decision and ordered the matter to proceed to trial, thus opening the University to private law attacks. ${ }^{133}$ As this case returns to trial, the question begged by the foregoing review of law is whether the University of Western Ontario, which was founded with a visitor, as I have shown above, retains the visitor at common law. If so, the visitor could be pleaded to foreclose Lam's private action and return the dispute to the University.

The lack of knowledge about visitors in the legal profession inhibits counsel's ability to plead the office. Without knowing what to look for, visitors cannot be found. This paper has attempted to elucidate the essential legal characteristics of visitors while showing how a visitor's jurisdiction has been applied. Going forward, counsel, judges, and legislators will need to consider the office on a case-by-case basis to determine whether charities ought to benefit from the jurisdiction. Facts in each case will need to be adduced to evaluate the jurisdiction. In so doing, a more holistic system of justice in universities and other charities might be achieved by ironing out legal rules relating to visitation. The founder's intentions along with institutions' unique ethos are more fully realized when clear rules may be applied. True to common law form, some intervention in the law is needed to create more certainty for litigants and judges alike.

2017 ONSC 6933, para 6.

133 Lam v University of Western Ontario, 2019 ONCA 82. 